\title{
Introduction to a Special Edition: Attachment Theory and its Application to Practice
}

\author{
Sherry R. Fairchild
}

Published online: 16 July 2009

(C) Springer Science+Business Media, LLC 2009

Although the form, scope, and function of the basic family unit have changed dramatically during the past one hundred years, the important role of the family unit as the foundation for personality development among its members still predominates. Attachment theory has evolved into a leading developmental and social personality model that stresses the importance of the primary caregiver-child relationship within family units. Bowlby (1984) proposed that infant attachment relationships provide the context in which working models of self and other are formed and that these working models play a key role in affect regulation and personality development. Ainsworth et al. (1978) developed a procedure, based on Bowlby's (1969/1982) model of attachment, called the "Strange Situation," to measure the quality of a child's attachment relationship with his or her parents (or primary caregivers). According to attachment theory, a felt sense of security in the attachment relationship offers the infant a "secure base" from which to explore the environment and a safe haven in times of uncertainty.

Bowlby (1980) asserted that with healthy development "attachment behavior leads to the development of affectional bonds or attachments" (p. 39). Such bonds, initially between child and parent, continue to be actively present throughout the life cycle (Bowlby 1973). Theoretically, these internalized bonds or working models continue to function as a secure base throughout the life course, providing the securely attached individual with an internalized model of self as worthy and an internalized model of the world as safe. These internal mental representations of attachment figures from childhood include both conscious and unconscious elements, impacting two significant interpersonal behavioral systems in adulthood: caregiving behaviors on behalf of others and care-eliciting for the self at times of

\footnotetext{
S. R. Fairchild ( $\bowtie)$

Psychosocial Psychiatric Rehabilitation, Central Texas Veteran's Affairs Health Care System,

Waco-VA Medical Center, BD 7, 1B-104, Waco, TX, USA

e-mail: Sherry.Fairchild@va.gov; sfairchild101@yahoo.com
} 
anxiety and threat (Solomon and George 1996). Bowlby (1984) also proposed that unmet attachment needs could result in numerous social problems in later life.

During the past 35 years attachment theorists have continued to generate an enormous amount of theoretical and empirical work regarding human attachment across the life span. Adult attachment research has branched out in several directions. One such branch focuses on the relationship between parenting behavior and early childhood attachment experiences. Another branch concerns the role of internal working models (mental representations of self and other) in influencing cognitive processes, emotion, and behavior (Crowell and Treboux 1995; George and West 1999). Additionally, adult attachment research has now extended into clinical issues such as persons with serious psychiatric disorders (Dozier and Lee 1995; Tyrrell et al. 1999), early attachment and development of later psychopathology (Fonagy 2003), women in inpatient treatment for trauma-related psychiatric disorders (Allen et al. 2001), adult attachment and mental illness (George and West 1999), attachment studies with borderline patients (Agrawal et al. 2004; Barone 2003; Fossati et al. 2001), relation of attachment status, psychiatric classification, and individuals' response to psychotherapy (Fonagy et al. 1996), and attachment patterns in violent and nonviolent husbands (Holtzworth-Munroe et al. 1997). See, for example, Dozier et al. (1999) for a review of the literature regarding the associations between adult representations of early relationships and the presence of later psychopathology.

This special issue presents a selection of studies and essays representing current progression in attachment theory and its application in mental health practice across the lifecycle, as well as in research. The articles in this special issue of Child and Adolescent Social Work Journal offer strategies to address attachment issues as illustrated with a variety of ages and different types of populations and ethnicities. The papers address the importance of the development of attachment-system functioning, as well as its impact at various stages of personality development and social behavior. These papers offer illustrations of various attachment interventions and expand the attachment knowledge base.

\section{References}

Agrawal, H. R., Gunderson, J., Holmes, B. M., \& Lyons-Ruth, K. (2004). Attachment studies with borderline patients: A review. Harvard Review of Psychiatry, 12(2), 94-104.

Ainsworth, M. S., Blehar, M. C., Waters, E., \& Wall, S. (1978). Patterns of attachment: A psychological study of the strange situation. Hillsdale, $\mathrm{NJ}$ : Erlbaum.

Allen, J. G., Huntoon, J., Fultz, J., Stein, H., Fonagy, P., \& Evans, R. B. (2001). A model for brief assessment of attachment and its application to women in inpatient treatment for trauma-related psychiatric disorders. Journal of Personality Assessment, 76(3), 421-447.

Barone, L. (2003). Developmental protective and risk factors in borderline personality disorder: A study using the adult attachment interview. Attachment \& Human Development, 5, 64-77.

Bowlby, J. (1969/1982). Attachment and loss: Vol. 1. Attachment (Vol. 1). New York: Basic Books.

Bowlby, J. (1973). Attachment and loss: Vol. 2. Separation, anxiety and anger. New York: Basic Books.

Bowlby, J. (1980). Attachment and loss: Vol. 3. Loss, sadness and depression. New York: Basic Books.

Bowlby, J. (1984). Violence in the family as a disorder of the attachment and caregiving systems. The American Journal of Psychoanalysis, 44(1), 9-27. 
Crowell, J. A., \& Treboux, D. (1995). A review of adult attachment measures: Implications for theory and research. Social Development, 4(3), 294-327.

Dozier, M., \& Lee, S. (1995). Discrepancies between self- and other-report of psychiatric symptomatology: Effects of dismissing attachment strategies. Development and Psychopathology, 7, 217226.

Dozier, M., Stovall, K. C., \& Albus, K. (1999). Attachment and psychopathology in adulthood. In J. Cassidy \& P. R. Shaver (Eds.), Handbook of attachment theory and research (pp. 497-519). New York: Guildford Press.

Fonagy, P. (2003). The development of psychopathology from infancy to adulthood: The mysterious unfolding of disturbance in time. Infant Mental Health Journal, 24(3), 212-239.

Fonagy, P., Steele, M., Steele, H., Leigh, T., Kennedy, R., \& Matton, G. (1996). The relations of attachment status, psychiatric classification, and response to psychotherapy. Journal of Consulting and Clinical Psychology, 64(1), 22-31.

Fossati, A., Donati, D., Donini, M., Novella, L., Bagnato, M., \& Maffei, C. (2001). Temperament, characters, and attachment patterns in borderline personality disorder. Journal of Personality Disorders, 15, 390-402.

George, C., \& West, M. (1999). Developmental vs. social personality models of adult attachment and mental ill health. British Journal of Medical Psychology, 72, 295-303.

Holtzworth-Munroe, A., Stuart, G. L., \& Hutchinson, G. (1997). Violent versus nonviolent husbands: Differences in attachment patterns, dependency, and jealousy. Journal of Family Psychology, 11, 314-331.

Solomon, J., \& George, C. (1996). Defining the caregiving system: Toward a theory of caregiving. Infant Mental Health Journal, 17, 183-197.

Tyrrell, C. L., Dozier, M., Teague, G. B., \& Fallot, R. D. (1999). Effective treatment relationships for persons with serious psychiatric disorders: The importance of attachment states of mind. Journal of Consulting and Clinical Psychology, 67(5), 725-733. 